\title{
Improving the properties of frozen shrimp by improving the characteristics of the surface ice glaze
}

\author{
Tatyana Duborasova ${ }^{1,2}$, Stanislav Kolobov ${ }^{2,3,}{ }^{,}$, and Elena Osipenko ${ }^{4}$ \\ ${ }^{1}$ Russian University of Cooperation, Russia \\ ${ }^{2}$ Russian Presidential Academy of National Economy and Public Administration, Russia \\ ${ }^{3}$ Plekhanov Russian University of Economics, Russia \\ ${ }^{4}$ Far Eastern State Agrarian University, Russia
}

\begin{abstract}
Research work was carried out on the introduction of various food additives in the icing of raw-frozen shrimp. This allowed us to preserve the quality indicators of shrimp, as well as to increase the shelf life from 4 months. up to six months.
\end{abstract}

\section{Materials}

According to the speaker of the Federation Council (FC) Valentina Matvienko, during the discussion of the new Strategy for the development of the fishery complex until 2030, Russians under consume on an average of $10 \mathrm{~kg}$ of fish and fishery products per year per capita. And in order to implement government goals of increasing exports and increasing the consumption of seafood in the country, it is necessary to harvest about 11 million tons annually, which is almost two times higher than current indicators [1-3].

In the Russian fish and seafood market, there is a tendency to develop and increase consumption. According to Rosstat, the market capacity increased by $3 \%$. In the first half of 2019 , Russian producers sold fish and seafood products for 350,000 million rubles, which exceeds the indicators of the same period in 2018 by $2.4 \%$ [4-5].

In general, the indicators of 2018 allow us to draw a conclusion about the emerging trend towards an increase in the volume of imports and exports of fish products in Russia, as well as an increase in the production volumes of the main domestic producers - table 1 .

The increase in fish and seafood production is explained by the policy of import substitution, as well as the policy of preference for this type of product [6].

In the seafood segment, previously oriented only to export there is also an increasing appeal to the Russian producer. To date, there are not so many brands on the Russian market of marine delicacies, and domestic brands make up a significant part of it.

The value of fish and fishery products is difficult to overestimate. Consumer properties of both fish and seafood are characterized by the content of basic nutrients. The variation in the content of these nutrients is significant, and depends on the place and time of fishing, the life stage of the animal, as well as the technological and merchan-

\footnotetext{
*Corresponding author: 97rus@mail.ru
} 
dising parameters of production, storage and transportation [7].

The proteins that make up the meat of aquatic organisms are not inferior in value to the proteins of meat from warm-blooded animals. Amino acids in meat proteins are in optimal ratios for human nutrition. Among them are all essential amino acids, including essential or limiting ones. If we talk about the quality of proteins and the ratio of amino acids in them, then seafood proteins are not inferior to the proteins of warmblooded animals. Sometimes they even surpass them, since they do not have connective tissue, and, in the backs, oxyproline and proline are not contained. The mass fraction of proteins in aquatic organisms ranges from 7-8\% (trepang, cucumaria) to $22-$ $23 \%$ (crustaceans, whale meat).

Table 1. Export and import of the Russian Federation of fish, fish products and seafood, million US dollars according to [4] (E - export; I - import).

\begin{tabular}{|l|c|c|c|c|c|c|c|c|}
\hline \multirow{2}{*}{ Products } & \multicolumn{2}{|c|}{2015} & \multicolumn{2}{c|}{2016} & \multicolumn{2}{c|}{2017} & \multicolumn{2}{c|}{2018} \\
\cline { 2 - 9 } & $\mathrm{E}$ & $\mathrm{I}$ & $\mathrm{E}$ & $\mathrm{I}$ & $\mathrm{E}$ & $\mathrm{I}$ & $\mathrm{E}$ & $\mathrm{I}$ \\
\hline $\begin{array}{l}\text { Fish and crustaceans, mol- } \\
\text { lusks and other aquatic inver- } \\
\text { tebrate }\end{array}$ & 3502 & 1356 & 3710 & 1400 & 4351 & 1632 & 5099 & 1802 \\
\hline $\begin{array}{l}\text { Of them: } \\
\text { Crustaceans live, fresh, } \\
\text { chilled, frozen, dried, salted } \\
\text { or in brine, thousand tons }\end{array}$ & 54.8 & 23.0 & 63.6 & 32.3 & 87.3 & 37.0 & 85.3 & 40.9 \\
\hline $\begin{array}{l}\text { Ready or canned crustaceans, } \\
\text { mollusks and other aquatic } \\
\text { invertebrates, thousand tons }\end{array}$ & 0.6 & 10.5 & 0.7 & 13.9 & 0.8 & 19.3 & 0.8 & 24.6 \\
\hline
\end{tabular}

In all invertebrates, the enzyme system is very strongly developed, which affects not only the safety of the product, but also its organoleptic characteristics. After the death of the shrimp, under the action of the enzymes in it, the decomposition and synthesis of new substances begins, which is called autolysis. The process can be visually observed in crustaceans by a color change. Unusual color means blackening, greening or yellowing of shrimp. The product in the form of crustaceans with an unusual color could contain no more than $25 \%$ of the sample.

It is the fact of the extraordinary activity of enzymes that explains the requirement to sell shrimp either alive or processed (heat and freezer). Using sluggish crustaceans is strictly prohibited.

Seafood fat is also very valuable from a biological point of view. Liquid fat: highly unsaturated fatty acids prevail in it, making this product necessary (vitamin F) - omega-acids. The presence of these unsaturated fatty acids makes the product prone to spoilage, especially under influence of oxygen and light.

Of the minerals in shrimp, phosphorus, calcium, and potassium are found in the greatest quantities. Of the trace elements - this is the presence of iodine and fluoride.

Vitamins are unevenly distributed: there is a small amount of fat-soluble vitamins - retinol, calciferol (called vitamin D3), tocopherol and vitamin K. Of the water-soluble vitamins of group B - B1, B2, B6, B12 were found [7].

Thus, shrimp is a very valuable food, biological product that is currently underestimated by the consumer. This is due to many factors, we will name some of them:

- Lack of attractive seafood on store shelves (especially in regions where this product requires long transportation and storage);

- $\quad$ Very high cost of fish products and seafood;

- $\quad$ Falsification of fish and seafood.

Let us dwell on the facts of falsification of seafood and fish. What are dishonest entrepreneurs and retailers doing in this direction? The list of violations is quite wide. 
- $\quad$ Sale thawed fish under chilled fish label -;

- Less valuable breeds of fish give out for more valuable, label medium size shrimp"Royal";

- $\quad$ Exceeding the norms of icing;

- Violation of the shelf life of the goods [8-9].

To preserve the quality of the shrimp and increase the shelf life, they are covered with ice crust (glaze). The icing helps maintain the presentation and quality of the shrimp during transportation and storage, as creates a protective ice layer. Due to this layer, moisture is not evaporated, the shrimp does not dry out, organoleptic characteristics and the mass of the goods are preserved. The EAEU Technical Regulations (TR) 040/2016 introduced restrictions on the content of glaze (ice) in shrimp: its mass fraction for peeled shrimp should not exceed 7\%, and for unbroken shrimp - 14\% of the total weight [10-12].

Manufacturers complain that the regulated amount of glaze does not allow preserving the quality of the goods in the warranty period (from 4 to 8 months of storage, depending on the degree of cutting, processing and packaging).

Hypothesis: If food additives are added to the glaze, this will not only preserve the quality of the shrimp, but also extend the shelf life of frozen products.

Objectives of the study: to develop and propose for sale a food supplement in ice icing, which would preserve the quality of raw-frozen shrimps in bulk and increase their guaranteed shelf life from 4 months to 6 months.

\section{Methods}

Unshared raw-born shrimps of medium weight according to GOST 20845-2017 were taken as an object of study [13].

Glaze of shrimps was glazed with drinking fresh water by forming a protective layer of ice on the surface of frozen shrimps when irrigated or immersed in this water with food additives dissolved in it.

As food additives used:

1) potassium sorbate plus sodium benzoate in equal amounts (total amount $0.15 \%$ );

2) the addition of sodium chloride in the amount of $3 \%$ in water for glazing;

3) the preservative "Special" company Nesse (Germany). This preservative was used according to the instructions of the company.

Prawns were glazed on automatic enrobing lines by irrigation with clean fresh water using irrigation-type equipment under industrial conditions. At the first stage, the shrimp were in the irrigation zone of the irrigation conveyor for 35 seconds, at the next - 7-10; to achieve a glaze thickness of $35-50 \%$. They had to go through three to four cycles of glazing. Each time after passing through the irrigation zone, the shrimp passed through a deepfreeze heat-insulating chamber, where they were frozen for 7-10 minutes. After the formation of the required thickness of the glaze and the final freezing at a temperature of -25 $\ldots-40{ }^{\circ} \mathrm{C}$ in a shock-freezing cabinet, frozen shrimp entered an additional conveyor, from where they fall onto a weighing table or packing line. To create a glaze that is transparent and resistant to mechanical influences, enrobing conveyors are equipped with water treatment and after-cooling systems. For glaze, fresh ice water cooled by chillers was used, to which the studied food additives were added. After that, the shrimp were stored at a temperature of minus $180 \mathrm{C}$ for 6 months. Together with the studied shrimp, control lots of shrimp developed in the traditional way were laid for storage.

The evaluation criteria were the microbiological parameters of the shrimp (the results were recorded) during the storage of products. In accordance with the guidelines for determining the shelf life of food products MUK 4.2.1847-04 "Epidemiological assessment of shelf life and storage conditions of food products", the number of studied groups of micro- 
organisms was determined at $0.01,0.1$ and $1.0 \mathrm{~g}$ of product [14-15].

At the end of the shelf life, the quality of the studied shrimp was determined by organoleptic methods: a descriptive and profile analysis method. In the descriptive method, the following product quality indicators were used as criteria [14]. The data are summarized in table 2 .

Table 2. Quality Indicators shrimp when sensory evaluation descriptive method.

\begin{tabular}{|l|l|}
\hline Name indicator & \multicolumn{1}{c|}{ Characteristic and norm } \\
\hline Appearance & Whole, regular shape, dense, clean, flat surface \\
\hline Colour & $\begin{array}{l}\text { Peculiar to this type of shrimp. } \\
\text { Allowed: } \\
\text { - slight darkening of the shell of the cephalothorax; } \\
\text { - meat light gray }\end{array}$ \\
\hline Meat consistency & Resilient \\
\hline Taste & Peculiar to boiled shrimp meat, sweetish, without extraneous taste \\
\hline Smell & Peculiar to this type of product, odorless \\
\hline
\end{tabular}

In this study, the organoleptic assessment of shrimp quality was determined according to a scale developed by the authors. The following characteristics of shrimp were chosen as quality indicators: surface condition, color of muscle tissue, smell, texture before and after boiling: taste, color of muscle tissue, smell, texture.

To develop the organoleptic evaluation system used in the work, a group of certified expert tasters was involved. When evaluating individual indicators, a five-point evaluation system was used. The results are presented in table 3 .

Table 3. Five-point organoleptic evaluation system of frozen shrimp.

\begin{tabular}{|c|c|c|c|c|c|}
\hline \multirow{2}{*}{$\begin{array}{l}\text { Quality } \\
\text { indicators }\end{array}$} & \multicolumn{5}{|c|}{ Quality Levels, Points } \\
\hline & 5 & 4 & 3 & 2 & 1 \\
\hline \multicolumn{6}{|c|}{ Raw product } \\
\hline $\begin{array}{l}\text { Surface } \\
\text { condition }\end{array}$ & $\begin{array}{l}\text { Whole, regular } \\
\text { shape, dense, the } \\
\text { surface is clean, } \\
\text { flat or with } \\
\text { slight hollows }\end{array}$ & $\begin{array}{l}\text { Whole, irregu- } \\
\text { lar, dense, } \\
\text { clean, uneven }\end{array}$ & $\begin{array}{l}\text { The surface } \\
\text { is dull, pale. } \\
\text { Mucous } \\
\text { membrane } \\
\text { may be pre- } \\
\text { sent. }\end{array}$ & $\begin{array}{l}\text { Covered } \\
\text { with muddy } \\
\text { mucus }\end{array}$ & $\begin{array}{l}\text { It is covered } \\
\text { with a mu- } \\
\text { cous film, a } \\
\text { mold or a } \\
\text { gray coating }\end{array}$ \\
\hline Muscle color & $\begin{array}{l}\text { Bright inherent } \\
\text { in this species }\end{array}$ & $\begin{array}{l}\text { Bright inherent } \\
\text { in this species; } \\
\text { color change is } \\
\text { possible - } \\
\text { blackening or } \\
\text { greening }\end{array}$ & $\begin{array}{l}\text { Pale. Strong } \\
\text { blackening or } \\
\text { greening }\end{array}$ & $\begin{array}{l}\text { Dull, signifi- } \\
\text { cant differ- } \\
\text { ences in } \\
\text { shades }\end{array}$ & $\begin{array}{l}\text { The predomi- } \\
\text { nance of } \\
\text { gray-greenish } \\
\text { shades, with } \\
\text { colored spots } \\
\text { of mold }\end{array}$ \\
\hline Smell & $\begin{array}{l}\text { Pleasant, } \\
\text { pronounced }\end{array}$ & $\begin{array}{l}\text { Pleasant, } \\
\text { moderately } \\
\text { expressed }\end{array}$ & $\begin{array}{l}\text { No } \\
\text { defamatory } \\
\text { signs }\end{array}$ & $\begin{array}{l}\text { Abruptly or } \\
\text { slightly ex- } \\
\text { pressed un- } \\
\text { pleasant }\end{array}$ & $\begin{array}{l}\text { Musty, putrid, } \\
\text { unusual for } \\
\text { shrimp }\end{array}$ \\
\hline Consistency & Tight, elastic & Resilient & $\begin{array}{l}\text { Soft, suppos- } \\
\text { edly weak- } \\
\text { ened, but } \\
\text { sloppy }\end{array}$ & $\begin{array}{l}\text { Exfoliating, } \\
\text { soft }\end{array}$ & Soft, weak \\
\hline \multicolumn{6}{|c|}{ Boiled product } \\
\hline Muscle color & $\begin{array}{l}\text { Homogeneous } \\
\text { inherent in this } \\
\text { species }\end{array}$ & $\begin{array}{l}\text { Inhomogene- } \\
\text { ous inherent in } \\
\text { this species }\end{array}$ & $\begin{array}{l}\text { Slight color } \\
\text { change }\end{array}$ & $\begin{array}{l}\text { Significant } \\
\text { color change }\end{array}$ & $\begin{array}{l}\text { Shrimp } \\
\text { unusual color }\end{array}$ \\
\hline Smell & $\begin{array}{l}\text { Pleasant, } \\
\text { pronounced }\end{array}$ & $\begin{array}{l}\text { Pleasant, mod- } \\
\text { erately pro- } \\
\text { nounced, with- } \\
\text { out extraneous } \\
\text { shades }\end{array}$ & $\begin{array}{l}\text { No defama- } \\
\text { tory signs. } \\
\text { Possible } \\
\text { slight smell } \\
\text { of oxidized } \\
\text { fat on the } \\
\text { surface }\end{array}$ & $\begin{array}{l}\text { Abrupt or } \\
\text { mild } \\
\text { unpleasant }\end{array}$ & $\begin{array}{l}\text { Musty, pu- } \\
\text { trid, unusual } \\
\text { for shrimp }\end{array}$ \\
\hline Consistency & $\begin{array}{l}\text { Resilient, tender, } \\
\text { juicy }\end{array}$ & Juicy, softened & $\begin{array}{l}\text { Soft, septi- } \\
\text { cally strati- } \\
\text { fied, a little } \\
\text { dry }\end{array}$ & $\begin{array}{l}\text { Weak, } \\
\text { smeared }\end{array}$ & $\begin{array}{l}\text { Slicking, } \\
\text { highly } \\
\text { delaminating }\end{array}$ \\
\hline Taste & $\begin{array}{l}\text { Pleasant } \\
\text { pronounced }\end{array}$ & $\begin{array}{l}\text { Pleasant } \\
\text { moderately } \\
\text { expressed }\end{array}$ & $\begin{array}{l}\text { Slight taste } \\
\text { of oxidized } \\
\text { fat }\end{array}$ & $\begin{array}{l}\text { Mild bitter, } \\
\text { off-flavors }\end{array}$ & $\begin{array}{l}\text { Unpleasant, } \\
\text { bitter, } \\
\text { unusual }\end{array}$ \\
\hline \multirow{2}{*}{$\begin{array}{l}\text { Quality } \\
\text { category }\end{array}$} & Highest & First & Second & Inferior food & $\begin{array}{l}\text { Technical } \\
\text { marriage }\end{array}$ \\
\hline & \multicolumn{3}{|c|}{ Standard } & \multicolumn{2}{|c|}{ Non-standard } \\
\hline
\end{tabular}




\section{Results}

Fig. 1 shows the dynamics of shrimp contamination growth during storage.

During the seven-month storage in ice, with various food additives in the icing, the total contamination in the shrimp samples did not exceed $1 \times 104 \mathrm{CFU} / \mathrm{g}$ (requirements of TS TC 040/2016)only in the additives that had potassium sorbate + sodium benzoate. This complies with the requirements established by the regulatory and technical document - not more than $1 \times 105 \mathrm{CFU} / \mathrm{g}$. It should be noted that the increase in total seeding exceeds the permissible levels for other food additives. However at 4 monthsall additives passed the test.

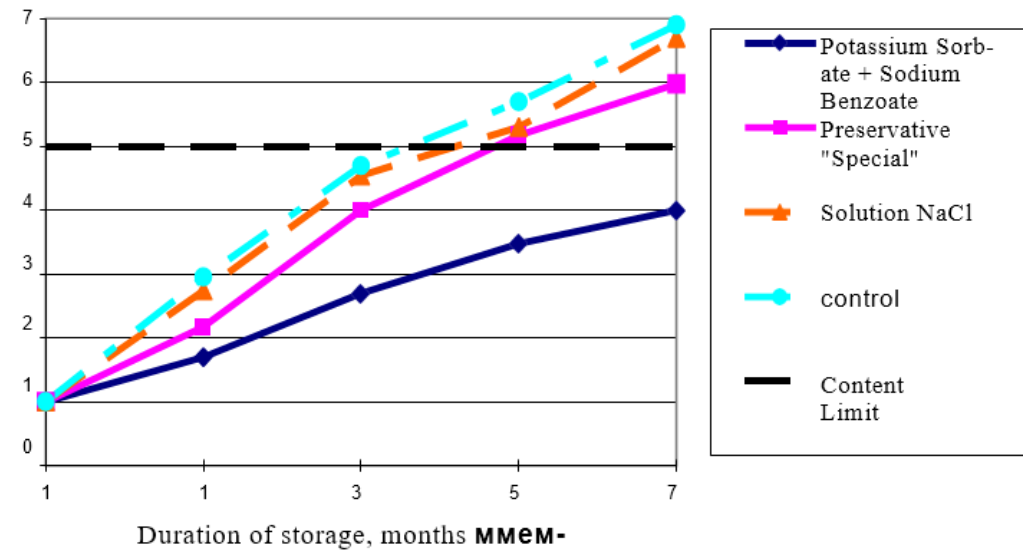

Fig. 1. The effect of food additives on the change in the indicator of total bacterial contamination $(\mathrm{N}$ KMAFAnM, CFU / g) of shrimp muscle tissue during storage.

A slight excess of seeding after 4 months ofstorage occurred in the control sample without food additives.

We arranged the nutritional supplements according to Fig. 1:

In the first place - Potassium sorbate + sodium benzoate in an amount of $0.15 \%$;

In second place - Special Preservative manufactured by Nesse (Germany);

In third place - a solution of sodium chloride in an amount of $3 \%$.

\section{Commodity assessment of shrimp}

Of great importance in assessing the quality is the organoleptic assessment of the quality of shrimp. Fig.s 2-4 show spider diagram of the organoleptic parameters of shrimp with various food additives of icing.

The result of the spider diagram evaluation allows us to conclude that a strong change in quality was observed during storage of shrimp with icing, to which a $3 \%$ solution of sodium chloride was added. The average score of all indicators was 3.75, which corresponds to a very low quality indicator - the second on our scale.

Control - shrimp simply glazed with water according to traditional technology did not withstand a shelf life of 6 monthsand were removed from the tasting.

The indicator with the preservative "Special" produced by Nesse (Germany) is slightly better - the average organoleptic rating was 4.52 , which corresponds to good quality or the first level on our scale. The highest rate was observed in shrimp stored in ice glaze with a dietary supplement of potassium sorbate + sodium benzoate. Their average organoleptic mark was 4.96, which corresponds to the highest quality. 


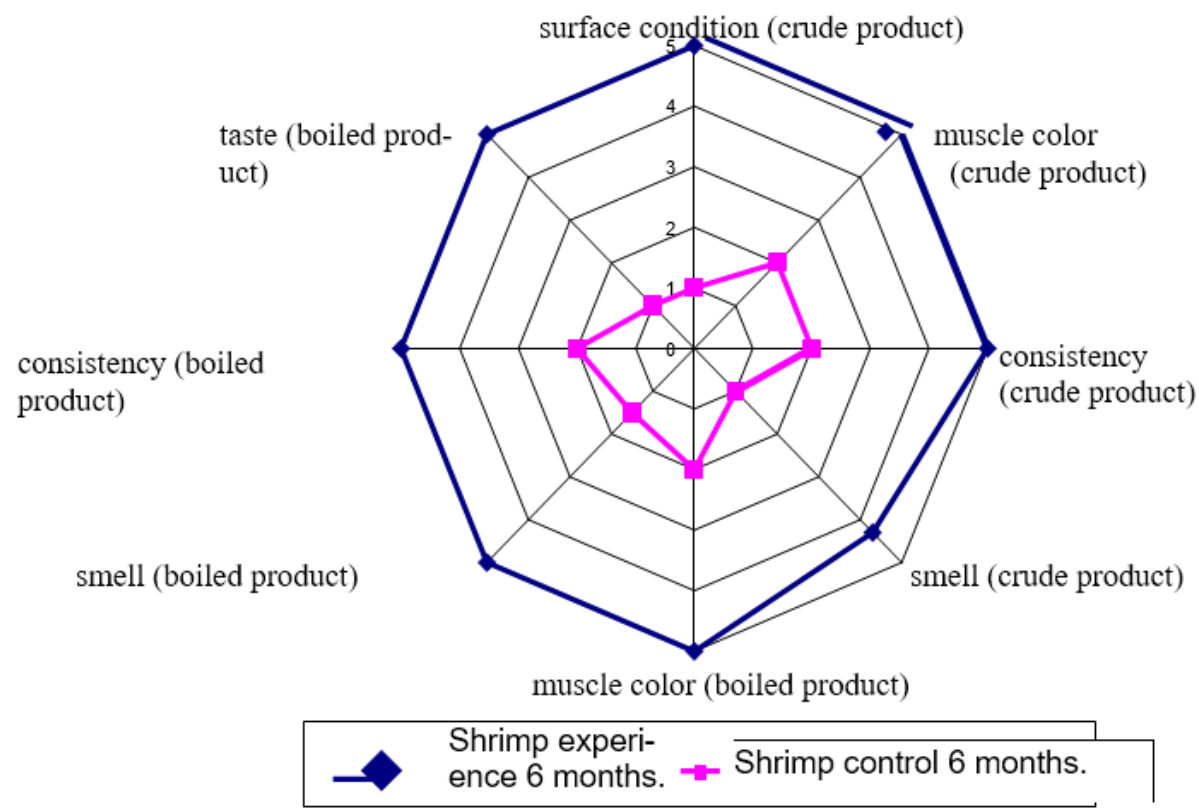

Fig. 2. Spider diagram of organoleptic characteristics of shrimp frozen with icing potassium sorbate + sodium benzoate in comparison with the control, stored 6 months.

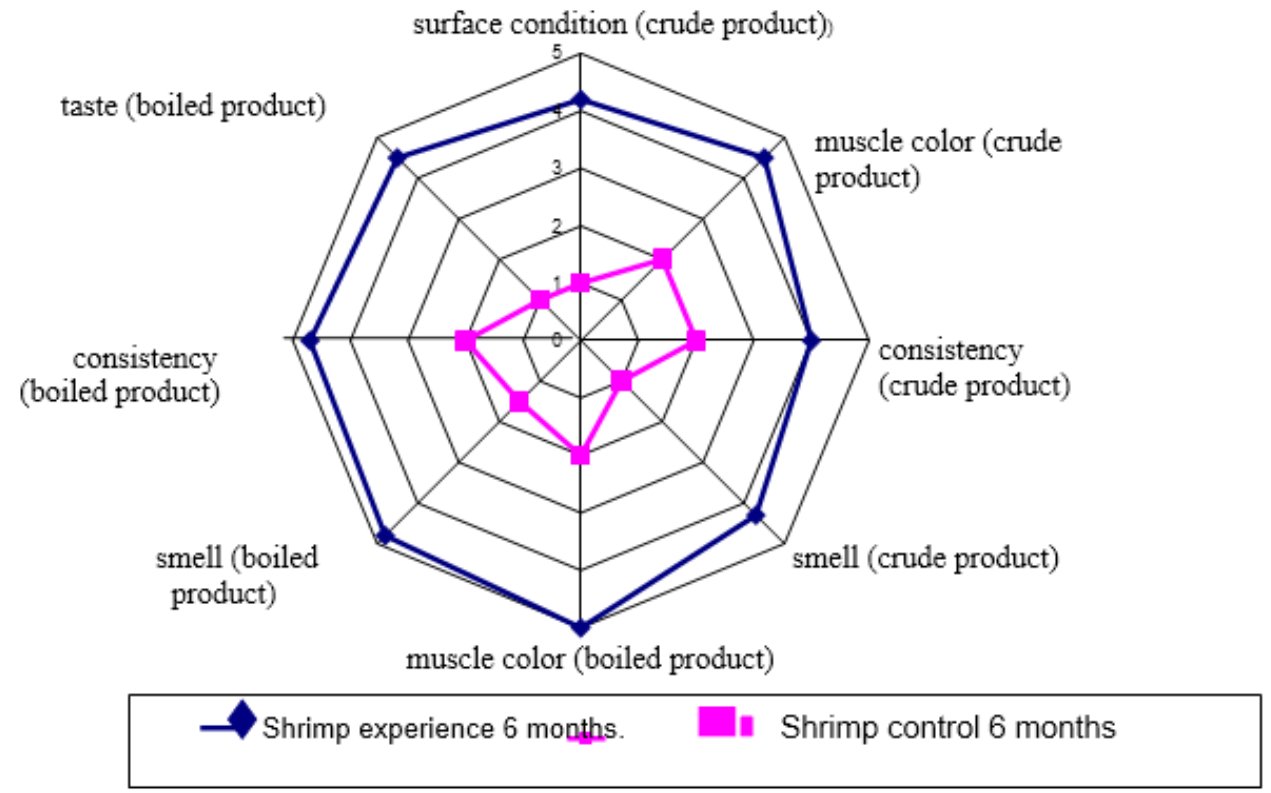

Fig. 3. Spider diagram of the organoleptic characteristics of frozen shrimp with icing and preservative "Special" manufactured by Nesse (Germany) in comparison with the control, stored 6 months. 


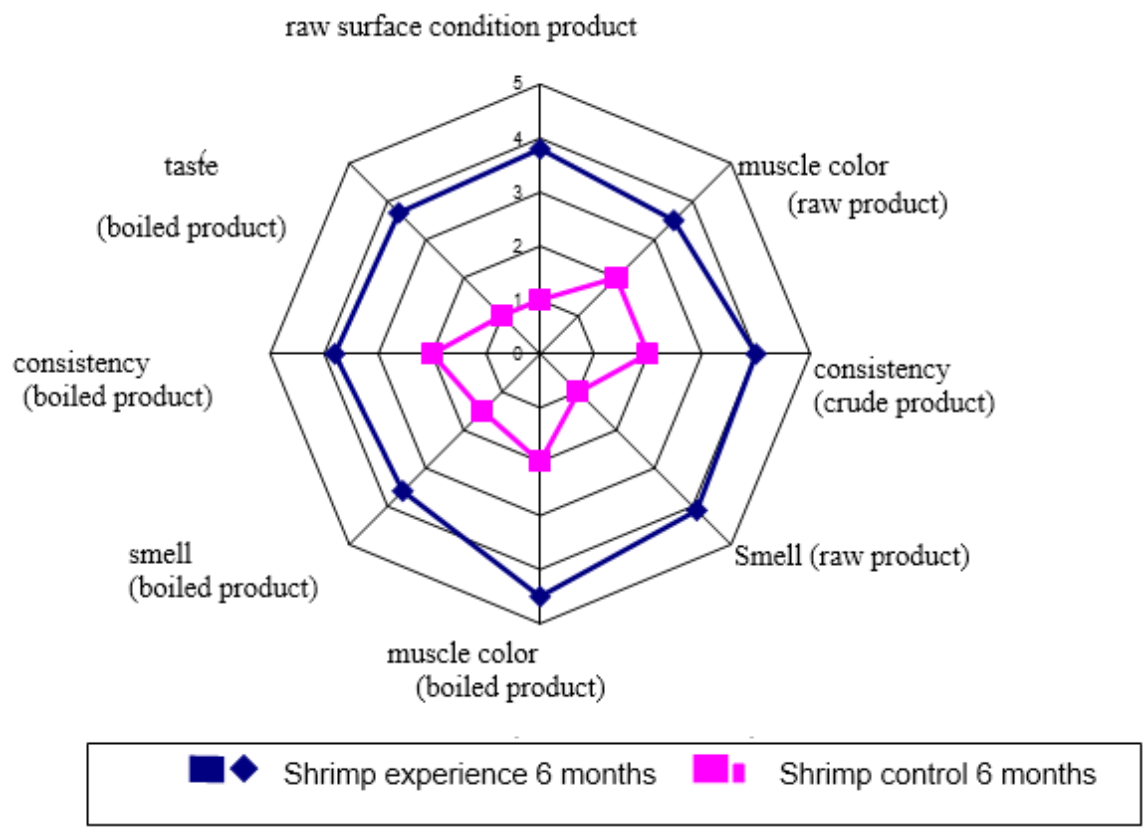

Fig. 4. Spider diagram of the organoleptic characteristics of shrimps frozen with icing and $3 \%$ sodium chloride solution in comparison with the control, stored for 6 months.

\section{Conclusions}

Based on the results of our study, the following conclusions were made:

1. Shrimp is a very beneficial food and biological product. Their introduction into the daily diet of the population will expand the range of consumed products of marine origin.

2. Currently, producers are limited in the production of shrimps with icing - its mass fraction for peeled shrimp should not exceed $7 \%$, and for unbroken - 14\% of the total weight.

3. To maintain the quality of the shrimp and increase the shelf life, the authors proposed to introduce food additives into the icing:

-Potassium sorbate + sodium benzoate in an amount of $0.15 \%$;

-Preservative "Special" manufactured by Nesse (Germany);

-A solution of sodium chloride in an amount of $3 \%$.

4. The best supplement for suppressing the bacterial flora was the food supplement Potassium sorbate + sodium benzoate; in second place is the Preservative "Special" manufactured by Nesse (Germany), the saline solution did not show the necessary results.

5. The introduction of these food additives made it possible to store shrimp not for 4 months, as stated in the regulatory document, but for 6 months.

\section{References}

1. Order of the Government of the Russian Federation of November 26, 2019 N 2798-r "On approval of the Development Strategy of the fishery complex of the Russian Federation for the period until 2030"

2. M.A. Nikolaeva, Y.N. Kleshhevskiy, O.A. Rjazanova The role of foreign trade in the development of Russia's fish goods market Russian foreign economic Bulletin. 10, 4107 (2017) 
3. O. Solovyova Russian seafood will be consumed by foreigners. The new strategy of the fishing industry is to export more Independent newspaper (2019)

4. Russia in numbers. Brief statistical compilation. Official statistical publications of ROSSTAT, (2019)

5. E R Yagmurov, G V Kozlov, M A Pushkarev, Lipase purification: the review of conventional and novel methods. Journal of Hygienic Engineering and Design 20, pp 6069 (2017)

6. Resolution of the Government of the Russian Federation of January 20, 2011 No. 11 "On approval of the rate of export customs duty on frozen deep-sea shrimps exported outside the States parties to the agreements on the Customs Union"

7. O.G. Mikhailova Biology of the northern shrimp pandalus eous makarov living off the coast of western Kamchatkacand. biol. Sciences 03.02.10 Hydrobiology, 26 (2017)

8. S. V. Talyzin, T. Yu. Duborasova Identification examination of frozen shrimps sold in retail in the Moscow region in the collection: Cooperation and entrepreneurship: status, problems and prospects: Kazan: RUK, 356-359 (2019)

9. M. A. Nikolaev, M. A. Polichnikova Identification and detection of adulteration of food products. Tutorial 464 (2020)

10. TR EAEU 040/2016: Technical Regulation of the Eurasian Customs Union "On the safety of fish and fish products"

11. TR EAEU 021/2011 Technical Regulation of the Eurasian Customs Union "About food safety"

12. Federal Law No. 268 - FZ of 22.12.2008 "On the quality and safety of food products"

13. GOST 20845-2017 Interstate standard GOST 20845-2017 " Frozen Shrimp. Technical conditions"

14. A. Gromov Formation of improved consumer properties of chilled fish by improving the characteristics of the cooling medium: autoref. dis. Cand. tech. 05.18.15Technology and commodity science of food products and functional and specialized purpose and public catering 28 (2010)

15. Methodical instructions of MUC 4.2.1847-04 "Epidemiological assessment of justification of shelf life and storage conditions of food products" (approved by the Chief state sanitary doctor of the Russian Federation 06.03.2004) 